\title{
Assessment of Knowledge, Practice, and Self- Efficacy for Patients with Chronic Obstructive Pulmonary Disease
}

\author{
Amora Omar D.N.Sc; Bahia Galal, D.N.Sc; Magda Mohamed D.N.Sc and \\ Ahmed El-sayed, M.D.
}

The Department of Medical-Surgical Nursing, Faculty of Nursing, Mansoura University, Medical-Surgical Nursing, Faculty of Nursing, Port Said University, Medical-Surgical Nursing, Faculty of Nursing, Ain Shams University. \& Respiratory Medicine, Faculty of Medicine, Mansoura University

\begin{abstract}
Abstract: Chronic obstructive pulmonary disease (COPD) is the fourth leading cause of morbidity and mortality throughout the world, resulting in a substantial and increasing economic and social burden. The aim of the present study was to assess knowledge, practice, and self efficacy for patients with COPD. A descriptive research design was used in this study. The sample consisted of 100 patients with COPD at the outpatient clinic of Respiratory Medicine, Mansoura University Hospital. Three tools were used to collect data, A structured interviewing questionnaire consisted of patient's sociodemographic characteristics and patient's medical history, patient's knowledge and practice questionnaire, and self-efficacy scale for patients with COPD. The results of the present study concluded that $96 \%, 93 \%$, and $86.0 \%$ of the studied subjects had low self efficacy, unsatisfactory knowledge, and unsatisfactory practices scores about COPD respectively. There was a significant statistical relation between patients' occupation and their total knowledge scores, and between patients' occupation and their total practice scores. However there was no significant statistical relation between patients' knowledge, practice and their self efficacy. The study recommended that an educational program should be conducted to improve knowledge, practice, and self efficacy for patients with COPD.
\end{abstract}

Aim :of the present study was to assess knowledge, practice, and self efficacy for patients with COPD.

Materials and Methods: A descriptive research design was used in the study. A convenience sample consisted of all available patients (100) patients with COPD at the outpatient clinic of Respiratory Medicine, Mansoura University Hospital. Three tools were used to collect data. 
Results: the present study concluded that $93 \%, 86 \%$, and $96.0 \%$ of the studied subjects had unsatisfied knowledge, poor practice, and low self efficacy scores about COPD respectively. There was significant statistical relation between patients' occupation and their total knowledge scores, and a significant statistical relation between patients' occupation and their total practice scores. However there was no significant statistical relation between patients' knowledge, practice and their self efficacy. The study recommended that an educational program should be conducted to improve knowledge, practice, and self efficacy for patient with COPD.

Recommendation: The study recommended that an educational program should be conducted to improve knowledge, practice, and self efficacy for patients with COPD.

Keywords: COPD - Knowledge - Practice - Self efficacy- Stable COPD.

Corresponding Author: Amora Omar, Faculty of Nursing, Mansoura University 


\section{Introduction}

Chronic Obstructive Pulmonary Disease (COPD) is a common preventable and treatable disease characterized by persistent airflow limitation that is usually progressive and associated with an enhanced chronic inflammatory response in the airways and lung to noxious particles or gases (The Global Initiative for Chronic Obstructive Lung Disease (GOLD), 2014).

Worldwide, COPD affects 329 million people or nearly 5\% of the population. In 2011, it ranked as the fourth-leading cause of death, killing over 3 million people, and it will become the third leading cause of death and the fifth leading cause of disability in 2030 (WHO, 2014). The number of deaths is projected to increase due to higher smoking rates and an aging population in many countries. It resulted in an estimated economic cost of \$2.1 trillion in 2010 (Lomborg, 2013).

In Egypt, Statistical analysis of COPD prevalence showed that 3 million from the Egyptian population have COPD. In different studies prevalence were from $3.3 \%$ up to $10 \%$ (El Hasnaoui, et al, 2012).

(Bandura, 1997\& Jones, 2006) defined self efficacy as a psychological construct which defines "the belief in one's capabilities to organize and execute the course of action required to produce given attainments", and may be fundamental to promoting effective self-management and enabling behavior change in the longer term .More simply, self-efficacy is what an individual believes he or she can accomplish using his or her skills under certain circumstances (Snyder \& Lopez, 2007). Self-efficacy has been thought to be a task-specific version of self-esteem (Lunenburg, 2011). 


\section{Significance of the study:}

The direct costs of COPD are the value of healthcare resources devoted to diagnosis and medical management of the disease. Indirect costs reflect the monetary consequences of disability, missed work, premature mortality and caregiver or family costs resulting from the illness (Sullivan, et al., 2000).

While patients claim to be well informed about coping with COPD, actual knowledge of COPD self-management is limited (Kessler, et al., 2006). For example, only 1 / 4 of patients with COPD have ever been told how to prevent dyspnea exacerbation .It has been suggested that this lack of awareness is related to the general absence of information available for COPD patients regarding social and behavioral dimensions of self-management (Hernandez ,et al., 2009).

Enhanced self-efficacy is fundamental to promoting effective self-management and enabling behavior change in the long term (Jones, 2007), and is a quantifiable mediator between disease and unnecessary activity restriction. Self-efficacy for coping with COPD has been shown to affect self-reported health related quality of life (HRQoL) more than measures of objective lung function (Kohler, et al., 2002). High self-efficacy predicts reduced psychosocial impact of disease, improved physical activity levels, and increased HRQoL .Conversely, low self-efficacy has been shown to predict poor self-management of COPD, while greater self-efficacy is associated with effective COPD self-management (Warwick,et al., 2010).

\section{Aim of the Study}

The study aimed to assess level of Knowledge, Practice, and Self efficacy for Patients with Chronic Obstructive Pulmonary Disease.

\section{Research questions:}

- What is the level of knowledge for patients with COPD?

- What is the level of practice for patients with COPD?

- What is the level of self efficacy for patients with COPD?

- Is there a relation between patients' Sociodemographic characteristics and their total level of knowledge, practice, and self efficacy?

- Is there relation between patients' level of knowledge, practices, and their selfefficacy? 


\section{SUBJECTS AND METHODS}

Research design: A descriptive exploratory design was utilized to meet the aim of this study.

Setting: This study was conducted at the outpatient clinic of Respiratory Medicine, Mansoura University Hospital from the beginning of May 2013 till end of October 2013.

Subjects: A convenience sample consisted of all available patients with stable COPD attended the outpatient clinic over a period of 6 months under the following criteria:

Inclusion Criteria:

- Adult patients between 20-60 years old.

- Both sexes.

Tools for data collection:

Three tools were used to collect data:Tool I: Biosocial-demographic and patient's health history structured Interviewing questionnaire:

It was developed by the researcher, based on recent and relevant literatures to assess socio-demographic characteristic of COPD patients .It was consisted of two main parts:

- Part 1: Patient's Sociodemographic characteristics: which included demographic characteristics of the patients which were composed of (7) closed ended questions including (age, sex, marital status, occupation, level of education, residence).

- Part 2: Patient's Medical History: which included series of questions to elicit patient's medical history, it was composed of:

a) Present medical history: It was composed of (6) closed ended questions including (duration of disease, presence of chronic diseases, drug compliance, smoking status, smoking type, and cigarette pack/year).

b) Past medical history: It was composed of (2) closed ended questions including (signs \& symptoms and history of hospitalization). 
c) Family history of the disease: It was composed of (2) closed ended questions which included (family history of COPD and degree of relativity).

\section{Body mass index}

Body weight was measured using weighing scale, and height was measured using measuring tape, patient weight was recorded in kilograms, patient height was measured using measuring tape; height was measured and recorded in meters. Body mass index was derived using measured height and weight with the following formula: $\mathrm{BMI}=$ weight $(\mathrm{kg}) /$ height $\left(\mathrm{m}^{2}\right)$. Parameters have been established to delineate underweight, normal weight and overweight. Body mass index categories: < 20 under weight, 20 to $<25$ desirable or normal weight, 25 to $<30$ overweight, 30 to 40 moderate obese and over 40 considered morbid obese (MacKay, 2010).

\section{Tool 2: Patient's Knowledge and practice questionnaire:}

It was developed by the researcher to assess level of patient's knowledge and practice, consisting of two main parts:

\section{A. Knowledge interviewing questionnaire:}

It was composed of (9) closed ended questions to elicit patient's knowledge related to COPD which included (definition of COPD, causes, Triggers, signs and symptoms, complication, treatment scope, medication, oxygen recommendations, and side effects of Medications).

\section{Scoring system:}

The total score for knowledge was (67), each question was scored as (zero) for incorrect answer, (1) for inadequate answer, and (2) for correct answer. Closed ended questions had points; these points were counted for each patient. The total score was calculated as follows:

- Satisfactory if the score $\geq 60 \%$ of the maximum score.

- Unsatisfactory if the score $<60 \%$ of the maximum score.

\section{B. COPD patients Practice's Observational checklist:}

It was adopted by researcher based on literature aimed to assess the level of patient's practice toward the following situations; resistance of smoking desire, avoidance of respiratory tract infection, avoidance of triggers that cause dyspnea, management of 
side effects of medication, clearance of discharges, management of dyspnea, management of anxiety and depression, avoidance of fatigue), and also \{breathing and coughing exercise, steps for using the inhaler, and nebulizer\}.

\section{Scoring system:}

Practice questionnaire sheet consisted of 8 questions and three procedures; each of 8 closed-ended question scored as (zero) for incorrect answer, (1) for inadequate answer, and (2) for correct answer. Points of closed ended questions were counted and then scored as satisfied practice if score $\geq 60 \%$ from the maximum score, and unsatisfied practice if $<60 \%$.

Scoring system of the three procedures; procedures of (breathing \& coughing exercise and steps for using the inhaler) each of them consisted of 6 items. Items were scored as following: Not done (0), and done (2). Total score for each of these procedures was (12). procedure of (steps for using nebulizer) consists of 16 items. Items were scored as following: Not done (0), and done (2). Total score for this procedure was (32). Points of three procedures were counted and then scored as correctly done if score $\geq$ $60 \%$ from the maximum score, and incorrectly done if $<60 \%$.

The total score for practices ( 8 closed-ended questions and three procedures was (72), and was scored as correctly done if score $\geq 60 \%$ from the maximum score, and incorrectly done if $<60 \%$.

Tool 3: Self-Efficacy scale for patients with COPD: adopted from (Wigal, et al., 1991):

CSES is 34 item questionnaires specifically assesses self-efficacy in individuals with COPD that consists of Likert scale with 5 responses "not at all confident, not very confident, somewhat confident, pretty confident, very confident" scoring 1 to 5 with 5 representing higher self-efficacy, and a five-factor structure including (negative affect, intense emotional arousal, physical exertion, weather/environments, and behavioral risk factors). It translated to simple Arabic language to facilitate data collection.

\section{Scoring system}

All questions are scored on a scale from 1 to 5 , with 5representing higher selfefficacy. Items were scored as following: (1) =Not at all confident. (2) = Not very confident. (3) = Somewhat confident. (4) = Pretty confident. (5) = Very confident. The total score for self efficacy was (170), Answers of questions were counted and 
then scored as high self efficacy if score $\geq 60 \%$ from the maximum score, and low self efficacy if $<60 \%$.

Operational Design: The Operational design included preparatory phase, content validity and reliability, pilot study and fieldwork.

Preparatory phase: It included reviewing of related literature and theoretical knowledge of various aspects of the study using books, articles, internet periodicals and magazines to develop the tool for data collection.

Content validity: Content validity was conducted to test the tool for appropriateness, relevance, correction and clearance through a jury of five experts. Four of them from the medical-surgical nursing staff at the faculties of nursing (Benha, Mansoura, and Port Said University). Juries were from different academic categories (professors, assistant professors, and lecture of medical surgical nursing ). And a professor of Respiratory Medicine, faculty of Medicine, Mansoura University. Their opinions were elicited regarding the tool format layout, consistency and scoring system.

Testing reliability: It was done through Cronbach Alpha Reliability Test that measure the degree of reliability for the entire form(0.985).

Pilot study: A pilot study was applied on a group of 8 patients for testing clarity, arrangement and time consuming to fill in the tools, the modification was done for the used tools then the final form was developed. Patients includes in the pilot study are excluded from the study group.

Fieldwork: The actual fieldwork started from beginning of May 2013 up to the end of October 2013 for data collection. (Within 6 months). The purpose of study was explained by the researcher to patients with COPD who agree to participate in the study prior to data collection to start the interview process by filling the interview questionnaire, the researcher reviewed each point in front of patients to be sure that no points are missed . Data was collected by the researcher over three days per week at the outpatient chest clinic of Mansoura University Hospital from 9:00 am to 1:00 pm. The time needed for completing the questionnaire was about 15 minutes for each patient.

\section{Statistical analysis:}

All collected data were organized, categorized, tabulated, entered, and analyzed by using SPSS, (Statistical Package for Social Sciences), software program version 14, 
which was applied to frequency tables, statistical significance and associations were assessed using the arithmetic mean, standard deviation (SD), chi-square, t-test, $\mathrm{Z}$ test, and coefficient correlation (r) to detect the relations between the variables.. Statistical significance was considered at $\mathrm{p}$ value $<0.05$.

\section{Results}

Table 1 Shows that $96.0 \%$ of the study subjects were in age group of 40-60 years old with Mean $\pm \mathrm{SD}=54.79 \pm 5.335,92.0 \%$ were males, $72.0 \%$ were married, and $54.0 \%$ of them were working. As regard to patients' level of education and residence, the table shows that $46.0 \%$ and $64.0 \%$ of the patients were illiterate and living in rural areas respectively.

Table 2 Shows that $50.0 \%$ of the study subjects had the disease for more than five years.67.0\% of the patients were compliant to medication. Regarding Smoking habits; it was observed that, $56.0 \%$ of the study subjects were previous smokers and $16.0 \%$ of them were current smokers.

Table 3 shows that there was significant statistical relation between patients' occupation and their total knowledge scores $(P$ value $=0.003)$.

Table 4 shows that there was a significant statistical relation between patients' occupation and their total practice scores $(\mathrm{P}$ value $=0.010)$.

Table 5 shows that there were no significant statistical relation between patient's personal characteristics and total self efficacy scores ( $\mathrm{P}$ value $>0.05)$.

Table 6 Shows that there were no statistical significant relation between patients' knowledge, total practice and level of self efficacy(P value>0.05).

Figure 1 shows that all patients who participated in the study had been exposed to different surrounding pollutants in form of: air pollution (72.0\%), rubbish burn (64.0\%), home animals (63.0\%), and factories $(15 \%)$.

Figure 2 shows that all the study subjects were obese in different degrees; $82.0 \%$ of them had moderate obesity, $3 \%$ had morbid obesity, and $15.0 \%$ were overweight.

Figure 3 shows that $93.0 \%$ of study subjects had unsatisfactory total knowledge scores about different areas of COPD. 
Figure 4 shows that $86.0 \%$ of the study subjects had unsatisfactory total practices scores regarding different areas of COPD.

Figure 5 shows that $96.0 \%$ of the study subjects had low total self- efficacy scores with Mean $\pm \mathrm{SD}=50.14 \pm 22.22$

\section{Discussion}

Sociodemographic Characteristics of the studied sample.

As regard to Age, the finding of present study revealed that, the most of study subjects were aged between 40 and 60 years old with mean age $54.79 \pm 5.33$ years, this finding is in accordance with Farag, et al. (2012) who reported that, the mean ages of patients were 55.1 \pm 7.3 . These findings may be due to that COPD takes many years until serious effects of smoking on lungs appear. this is supported by Centers for Disease Control and Prevention (CDC), (2011) that stated that COPD is most common in older people because symptomatic COPD usually takes more than 20 pack-years of smoking to develop.

As regard to gender, the result of the present study showed that, the majority of study subjects were male. This finding is in agreement with Altimiras, et al. (1992) who stated that, the majority of patients studied were males. This may be due to higher prevalence of smoking in this gender in Egypt; Also men are more exposed to smoking than females and occupational exposure are significant in males. However this finding is in contrast with Scott, et al. (2011) who reported that 53\% were women.

In relation to marital status, the study finding showed that, about three quarters of the study subjects were married. This finding might be due to the same age groups of the studied sample. This finding is in accordance with Abedi, et al. (2013) who found that the majority of the studied Sample was married. This finding is in contrast with Jacobsen, et al. (2014) who stated that more than two thirds of the sample was single.

Regarding occupation, the current study portrayed that, more than half of the study subjects were working. This finding is in agreement with Farag, et al. (2012) who reported that three quarters (75\%) of studied sample were working. This may be due to patients continued to work when they are able to cover high cost of medications and to help their families. 
Concerning to educational level, the studied sample showed that; near half of the patients were illiterate, while minority of them had completed university degree. This finding might be due to the majority of patients were from rural area with Less attention to education and low level of health awareness. This finding is in agreement with Bratas, et al. (2010) who reported that $13.2 \%$ of studied sample had university degree, and Farag, et al. (2012) who reported that $41 \%$ of studied sample were illiterate. This finding is in contrast with Mohamed (2005) who stated that, two fifth of the study group had high level education, while few of them were illiterate.

Regarding residence, the results of this study revealed that two thirds of patients were from rural area, the possible explanation for the large percent is present from rural area may be due to lack of health care centers and decrease population health awareness in Egyptian rural areas. This finding is in acceptance with Gupta et al, (2010) who reported that more than one third of the sample was from urban area. This

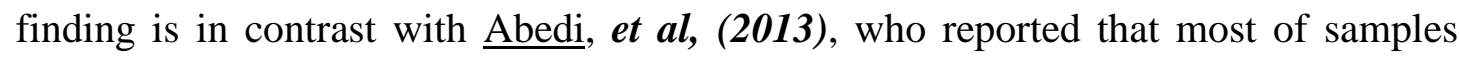
were from the city $80.6 \%$.

As regard to surrounding's home pollutants, the present study revealed that, about three quarter of the studied subjects had exposed to air pollution, about two thirds of them had exposed to rubbish burn and had home animals. These findings are supported by WHO (2014) that stated in low-income countries exposure to indoor air pollution causes the COPD burden, and with $\mathbf{L i u}$, et al (2008) who stated that outdoor and indoor air pollutants can cause or exacerbate COPD.

In relation to body mass index of the study subjects, the result showed that, all patients were obese in different degrees; most of them had moderate obesity while the minority of them had morbid obesity. This finding is in accordance with Hassanein (2007), who stated that most of the COPD study subjects were either overweight or obese.

Regarding to patients' knowledge about different areas of COPD, the findings of the present study revealed that the majority of studied subjects had unsatisfied total knowledge scores about COPD. This result goes in the same line with Wong, et al. (2014) who stated that knowledge about COPD was generally poor, and with Reema, et al. (2010), who found that the base line results of COPD patients had poor perception of their disease. The finding of the current study might be due to near half 
of the patients were illiterate or might be due to work overload of health team which leads to neglecting to provide patients with information needed for adaptation with their disease.

This finding goes in the same line with Youmans and Schillinger, (2003) who stated that limited educational attainment, inadequate health literacy skills, are the cause that patients lack basic knowledge about their major disease states., and with Hernandez, et al. (2009) who stated that lack of awareness about COPD is related to the general absence of information available for COPD patients regarding social and behavioral dimensions of self-management.

As regard to patient's practice, the findings of the present study revealed that the majority of the studied subjects had poor total practices scores, this might be due to lack of clinical procedures and unavailability of instruction resources about disease treatment. This result is in agreement with Reema et al. (2010) who reported that the COPD patient's practices were below the mark.

As regard to patient's practices toward Breathing \& coughing exercise and Nebulizer technique procedures, the finding of present study revealed that, more than three quarter of the studied subjects had poor practice scores. This finding is in agreement with Newman (2005) who stated that nebulizers are generally bulky, inconvenient, can be expensive, and require regular maintenance and long treatment times.

Concerning patients' practices toward Inhaler technique procedure, the finding of present study revealed that, the majority of studied subjects had good practice score about using it. This finding may be due to this technique is one of the basic procedures that must be done as obligatory teaching to the patient on the first session with health care providers. This finding goes in the same line with Souza, et al. (2009) who reported nearly all of the COPD patients claimed to know how to use inhalation devices correctly, and with Hernandez, et al., (2009) who stated that inhalers were reported as effective by $89 \%$ of respondents, however this finding is in contrast with Reema, et al., (2010) who revealed that, although all patients shook the canister before using the medication, none of them had proper inhalation technique, and with Serra-Batlles, et al. (2002) who stated that up to $85 \%$ of COPD patients use their inhaler ineffectively. 
As regard to self efficacy: The finding of present study revealed that, most of studied subjects had low total self efficacy scores regarding the five subscales of CSES including : negative affect, intense emotional arousal factor, physical exertion factor, weather/environment factor , and behavioral risk factors. These findings are in agreement with Inal-Ince, et al. (2005) who found the same result, and with Abedi, et al. (2013) who found that patients with COPD had low self-efficacy scores before implementing educational interventions, Stellefson, et al. (2012) who stated that there was no significant improvement between 1-month and 2-month follow up across any of the 5 dimensions of self-efficacy, and with Kara Kaşikçi \& Alberto (2007) who stated that only $(12.5 \%)$ perceived self-efficacy as high.

As regard to relation between socio-demographic characteristics of studied subjects with COPD and their total knowledge scores; the current study revealed that there was a significant statistical relation between patients' occupation and their total knowledge scores. This finding is in contrast with Ray, et al. (2013) who stated that COPD patients' knowledge scores were significantly related to health literacy and educational attainment.

Concerning to relation between socio-demographic characteristics of patients with COPD and total Self efficacy scores of the studied subjects, the current study revealed that, there were no significant statistical relation between patient's personal characteristics and self efficacy scores. This finding goes in the same line with Chan (2008) who stated that, the results didn't show any relation between levels of self efficacy and socio-demographic characteristics of the study subjects.

As regard to relation between total self efficacy, total knowledge and, total practices, this result revealed that there was no statistical significant relation between patients' self efficacy, and their knowledge or practices. This finding is in contrast with Kara Kaşikçi \& Alberto (2007) who stated that there were statistically significant positive relationship between self-efficacy and practice $(\mathrm{p}=0.01)$ and with Kohler, et al. (2002) who reported that individuals with low perceived self-efficacy were more limited in functioning than those with equally severe disease but who had higher perceived selfefficacy for carrying out activities. 


\section{Conclusion}

Based on the results of the present study, the following can be concluded:

The majority of the study subjects $(93 \%)$ had unsatisfactory knowledge scores about COPD, the majority of the studied sample $(86 \%)$ had poor total practices scores, and most of the studied subjects $(96.0 \%)$ had low total self efficacy scores.

There were no significant statistical relations between patient's sociodemographic characteristics and their knowledge except for occupation $(\mathrm{P}$ value $=0.003)$, Also there was a significant statistical relation between patient's occupation and their total practice $(\mathrm{P}$ value $=0.010)$. There is no statistical significant relation between patients' knowledge, total practices and level of self efficacy.

\section{Recommendations}

\section{Based on the results and conclusions of the current study, the following recommendations are suggested:}

- Self care guidelines to improve patients' knowledge and practice toward COPD.

- Continuous educational programs for patients with COPD and their family about COPD management, complication, and ways of prevention.

- Continuous monitoring and evaluating Self efficacy for patients with COPD to enhance disease management.

- Establish a rehabilitation program for patient with COPD to improve their self efficacy.

\section{References}

Abedi, H., Salimi, S., Feizi, A., and Safari, S. (2013): Effect of Self-efficacy Enhancement Program on Self-care Behaviors in Chronic Obstructive Pulmonary Disease. Iran J Nurs Midwifery Res; 18(5):421-4.

Altimiras, J., Borras J., Mendez, E., Pastor, E., and Bassons, T. (1992): Knowledge of Medication in Hospitalized Chronic Respiratory Patients. Pharm Weekbl Sci; 14(4):174-9.

Bandura, A. (1997): The Nature and Structure of Self-efficacy. In: A Bandura (ed). Self-efficacy: The Exercise of Control. New York: W.H. Freeman, pp: 36-78. 
Bratas, O., Espnes, G., Rannestad, T., and Walstad, R. (2010): Characteristics of Patients with Chronic Obstructive Pulmonary Disease Choosing Rehabilitation .J Rehabil Med; 42(4): 362-367.

Centers for Disease Control and Prevention (CDC). (2011): Chronic Obstructive Pulmonary Disease among Adults aged 18 and over in the United States, 1998-2009. Available at: http://www.cdc.gov/mmwr/preview/mmwrhtml/ rr6207a1.htm .Accessed on 24- 4- 2014 .

Chan, R. (2008): Along Term Evaluation of the Impact of Rehabilitation in Home (RIO) Program on Health Outcome in Older Adults. Published Thesis, Master Degree Thesis, Faculty of Health (Centre for Health Research-Nursing), Queensland University of Technology, p.73.

El Hasnaoui, A., Rashid, N., Lahlou, A., Salhi, H., Doble, A., and Nejjari, C.; BREATHE Study Group (2012):Chronic Obstructive Pulmonary Disease in the Adult Population within the Middle East and North Africa Region: Rationale and Design of the BREATHE Study. Respir Med; 106 (2): 3-15.

Farag,T., Hafez, M., Elshafie,T., and Abo-Elkheir, O.(2012): Anxiety and Depression among Patients with Bronchial Asthma, Chronic Obstructive Pulmonary Disease, and Diffuse Paranchymatios Lung Disease. The Eygptian Journal of hospital medicine; 49;718-731.

Global Initiative for Chronic Obstructive Lung Disease (GOLD), (2014): The Global Strategy for the Diagnosis, Management and Prevention of COPD. Available at: http://www.goldcopd.org/guidelines-global-strategy-for-diagnosismanagement.html. Accessed on 18-4- 2014.

Gupta, B., Kant, S., Mishra, R., and Verma, S. (2010): Nutritional Status of Chronic Obstructive Pulmonary Disease Patients Admitted in Hospital with Acute Exacerbation. J Clin Med Res; 2(2):68-74.

Hassanein, S.E., Narsavage, G.L., Williams, S.D., Anthony, M.K., and Gittner, L.S. (2007): Which Chronic Obstructive Pulmonary Patients will be likely to attend Consistently a pulmonary Rehabilitation Program , Perm J. ; 11(4): 50-53.

Hernandez, P., Balter, M., Bourbeau, J., and Hodder, R. (2009): Living with Chronic Obstructive Pulmonary Disease: A Survey of Patients' Knowledge and Attitudes. Respir Med; 103(7):1004-12. 
Inal-Ince, D., Savci, S., Coplu, L., and Arikan, H. (2005): Factors Determining Self-efficacy in Chronic Obstructive Pulmonary Disease. Saudi Med J; 26(4):542-7. Jacobsen, R ., Rusch, E., Andersen ,P., Adams, J., Jensen, C., and Frølich, A.(2014): The Effect of Rehabilitation on Health-care Utilisation in COPD Patients in Copenhagen. Clin Respir J; 8(3):321-9.

Jones, F. (2006): Strategies to Enhance Chronic Disease Self-Management: How Can We Apply This to Stroke? Disabil Rehabil; 28 (13-14): 841-7.

Jones, R. (2007): Too Little, Too Late - the Patients' Perspective on Education for COPD. Chronic Respiratory Disease; 4 (4): 189-190.

Kara Kaşikçi, M . and Alberto, J. (2007): Family Support, Perceived Self-efficacy and Self-care Behavior of Turkish Patients with Chronic Obstructive Pulmonary Disease. J Clin Nurs. ;16(8):1468-78.

Kessler, R., Stahl, E., Vogelmeier ,C., Haughney, J., Trudeau , E., Löfdahl, C., and Partridge, M. (2006): Patient Understanding, Detection, and Experience of COPD Exacerbations: An Observational, Interview-Based Study. Chest; 130(1): 13342.

Kohler, C., Fish, L., and Greene, P. (2002): The Relationship of Perceived SelfEfficacy to Quality of Life in Chronic Obstructive Pulmonary Disease. Health Psychol; 21(6), pp: 610-4.

Liu, Y ., Lee, K., Perez-Padilla, R., Hudson, N., and Mannino, D.(2008): Outdoor and indoor air pollution and COPD-related diseases in high- and low-income countries. Int J Tuberc Lung Dis; 12(2):115-27.

Lomborg, B. (2013): Global Problems, Local Solutions: Costs And Benefits, 1st ed.,New York: Cambridge University, Pres., p: 143.

Lunenburg, F. (2011): Self-Efficacy in the Workplace: Implications for Motivation andPerformance. International Journal of Management, Business, and Administration; $14(1)$.

MacKay, N.J. (2010): Scaling of human body mass with height: The body mass index revisited. J Biomech. ;43(4):764-6.

Mohamed, A. (2005): Pulmonary Rehablitation: Self care Strategies for Chronic Obstructive Pulmonary Disease Patients. Unpublished Thesis, Doctorate Thesis, Medical -Surgical Nursing Department Faculty of Nursing, Ain Shams University, Pp. 120-150. 
Newman, S.P. (2005): Inhaler treatment options in COPD. Eur Resp Rev; 14:102108.

Ray, S., Helmer, R., Stevens, A., Franks, A., and Wallace, L.(2013): Clinical Utility of the Chronic Obstructive Pulmonary Disease Knowledge Questionnaire. Fam Med; 45(3):197-200.

Reema, T., Adepu, R., and Sabin, T. (2010): Impact of clinical pharmacist Intervention on Knowledge, Attitude and Practice (KAP) of patients with chronic obstructive pulmonary disease. International Journal of Pharmacy \& Pharmaceutical Sciences; 2(4); 54.

Scott, A., Baltzan, M., Dajczman, E., and Wolkove, N. (2011): Patient Knowledge in Chronic Obstructive Pulmonary Dsease: Back to Basics. COPD; 8(5):375-9.

Serra-Batlles, J., Plaza, V., Badiola, C., and Morejón, E. (2002): Inhalation Devices Study Group.P atient perception and acceptability of multidose dry powder inhalers: a randomized crossover comparison of Diskus/Accuhaler with Turbuhaler. J Aerosol Med.; 15(1):59-64.

Snyder, C. R. and Lopez, S. J. (2007): Positive psychology: The Scientific and Practical Explorations of Human Strengths, Thousand Oaks, CA: Sage Publications, Pp: 297-321.

Souza, M., Meneghini, A., Ferraz, E., Vianna, E., and Borges, M.(2009): Knowledge of and technique for using inhalation devices among asthma patients and COPD patients. J Bras Pneumol ; 35(9):824-31.

Stellefson,M., Tennant,B., and Don Chaney,J. (2012): A Critical Review of Effects of COPD Self-Management Education on Self-Efficacy. Public Health; 2012 (2012): 10 .

Sullivan S.,Ramsey S., and Lee, T - (2000): The Economic Burden of COPD. Chest; 117(2):5-9.

Warwick, M., Gallagher, R., Chenoweth, L., and Stein-Parbury, J. (2010): SelfManagement and Symptom Monitoring Among Older Adults with Chronic Obstructive Pulmonary Disease, Journal of Advanced Nursing; 66(4): 784-793.

Wigal, J.,Creer,T., and Kotses, H. (1991): The COPD Self-Efficacy Scale.Chest; 99(5): 1193-6. 
Wong, S., Abdullah, N., Abdullah, A., Liew, S., Ching, S., Khoo, E., Jiwa, M., and Chia, Y. (2014): Unmet Needs of Patients with Chronic Obstructive Pulmonary Disease (COPD): A Qualitative Study on Patients and Doctors. BMC Fam Pract; 15(1):67.

World Health Organization (2014d): The 10 Leading Causes of Death in the World, 2000 and 2011. Available at: http://www.who.int/mediacentre/factsheets/fs310/en/. Accessed on 28- 4- 2014.

World Health Organization (WHO) (2014f): Causes of COPD, Retrieved April 24, 2014 Available at: http://www.who.int/respiratory/ copd/causes/en/. .Accessed on 244- 2014.

Youmans, S.L. and Schillinger, D.(2003): Functional Health Literacy and Medication Use: The Pharmacist's Role. Ann Pharmacother;37:1726-9. 
Results:

Table (1): Socio-demographic Characteristics of Patients with COPD (N=100):

\begin{tabular}{|c|c|c|}
\hline Personal Characteristics & No. $=100$ & $\%$ \\
\hline $\begin{array}{l}\text { Age groups (in years) } \\
\text { - } 20- \\
\text { - } \quad 40-60\end{array}$ & $\begin{array}{c}4 \\
96\end{array}$ & $\begin{array}{c}4.0 \\
96.0\end{array}$ \\
\hline \multicolumn{3}{|l|}{ Mean \pm SD $\quad=54.79 \pm 5.335$} \\
\hline $\begin{aligned} \text { Gender } \\
\text { - } \\
\text { - } \text { Male } \\
\text { Female }\end{aligned}$ & $\begin{array}{c}92 \\
8\end{array}$ & $\begin{array}{c}92.0 \\
8.0\end{array}$ \\
\hline $\begin{array}{cl}\text { Marital status } \\
\text { - } & \text { Single } \\
\text { - } & \text { Married } \\
\text { - } & \text { Divorced } \\
\text { - } & \text { Widowed }\end{array}$ & $\begin{array}{c}4 \\
72 \\
10 \\
14\end{array}$ & $\begin{array}{l}4.0 \\
72.0 \\
10.0 \\
14.0\end{array}$ \\
\hline $\begin{array}{ll}\text { Occupation } \\
\text { - Working } \\
\text { - Not working }\end{array}$ & $\begin{array}{l}54 \\
46\end{array}$ & $\begin{array}{c}54.0 \\
46.0\end{array}$ \\
\hline $\begin{array}{l}\text { Level of education } \\
\text { - } \quad \text { Illiterate } \\
\text { - } \quad \text { Read and write } \\
\text { - } \text { secondary } \\
\text { - University }\end{array}$ & $\begin{array}{c}46 \\
30 \\
20 \\
4\end{array}$ & $\begin{array}{c}46.0 \\
30.0 \\
20.0 \\
4.0\end{array}$ \\
\hline $\begin{aligned} & \text { Residence } \\
& \text { - } \text { Rural } \\
& \text { - } \text { Urban }\end{aligned}$ & $\begin{array}{l}64 \\
36\end{array}$ & $\begin{array}{l}64.0 \\
36.0\end{array}$ \\
\hline Total & 100 & 100.0 \\
\hline
\end{tabular}


Table (2): Present Health History of patients with COPD $(\mathrm{N}=100)$.

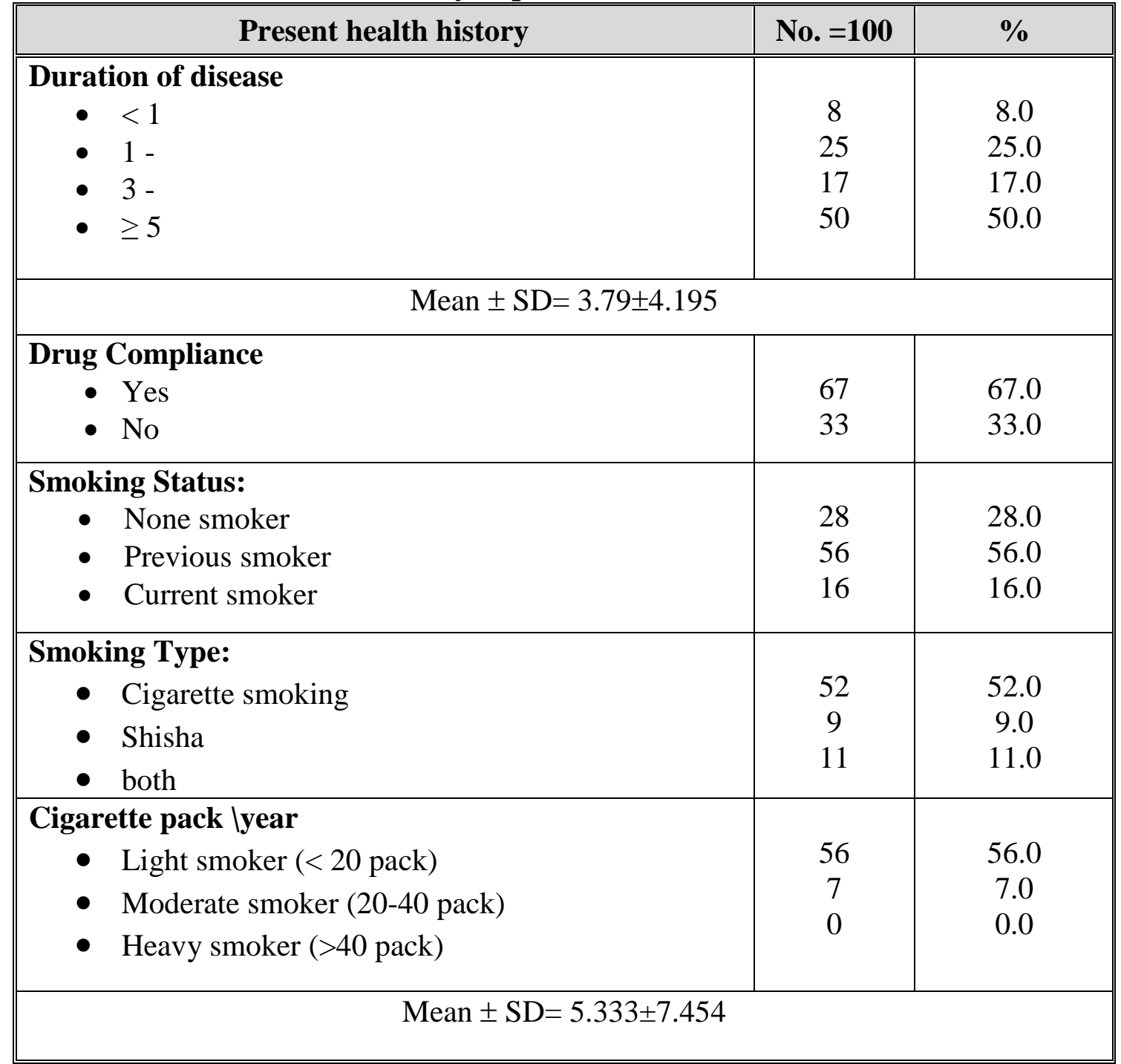


Table (3): Relation between Socio-demographic Characteristics of Patients with COPD and their Total Knowledge Scores: (N=100).

\begin{tabular}{|c|c|c|c|c|c|c|}
\hline \multirow{2}{*}{$\begin{array}{l}\text { Level of Knowledge } \\
\text { Sociodemographic } \\
\text { characteristics }\end{array}$} & \multicolumn{2}{|c|}{$\begin{array}{c}\text { Satisfactory } \\
\text { Knowledge } \\
\text { No=7 }\end{array}$} & \multicolumn{2}{|c|}{$\begin{array}{c}\text { Un } \\
\text { satisfactory } \\
\text { Knowledge } \\
\text { No=93 }\end{array}$} & \multirow[t]{2}{*}{$\mathbf{X} 2$} & \multirow[t]{2}{*}{$\begin{array}{c}P . \\
\text { value }\end{array}$} \\
\hline & No. & $\%$ & No. & $\%$ & & \\
\hline $\begin{array}{l}\text { Age in years: } \\
\text { - } 20- \\
\text { - } 40-60\end{array}$ & $\begin{array}{l}4 \\
3\end{array}$ & $\begin{array}{l}4.0 \\
3.0\end{array}$ & $\begin{array}{c}0 \\
93\end{array}$ & $\begin{array}{c}0.0 \\
93.0\end{array}$ & 0.396 & 0.529 \\
\hline $\begin{array}{lll} & & \text { Sex: } \\
\text { - } & \text { Male } \\
\text { - } & \text { Female }\end{array}$ & $\begin{array}{l}7 \\
0\end{array}$ & $\begin{array}{l}7.0 \\
0.0\end{array}$ & $\begin{array}{c}85 \\
8\end{array}$ & $\begin{array}{c}85.0 \\
8.0\end{array}$ & 0.655 & 0.419 \\
\hline $\begin{array}{ll} & \text { marital status: } \\
\text { - } & \text { Single } \\
\text { - } & \text { Married } \\
\text { - } & \text { Divorced } \\
\text { - } & \text { Widow }\end{array}$ & $\begin{array}{l}1 \\
5 \\
1 \\
0\end{array}$ & $\begin{array}{l}1.0 \\
5.0 \\
1.0 \\
0.0\end{array}$ & $\begin{array}{c}3 \\
67 \\
9 \\
14\end{array}$ & $\begin{array}{c}3.0 \\
67.0 \\
9.0 \\
14.0\end{array}$ & 3.183 & 0.364 \\
\hline \begin{tabular}{|ll} 
Occupation \\
$\qquad \quad$ Working \\
$\bullet \quad$ Not working
\end{tabular} & $\begin{array}{l}7 \\
0\end{array}$ & $\begin{array}{l}7.0 \\
0.0\end{array}$ & $\begin{array}{l}47 \\
46\end{array}$ & $\begin{array}{l}47.0 \\
46.0\end{array}$ & 8.836 & $0.003^{*}$ \\
\hline \begin{tabular}{|l} 
Educational level \\
- $\quad$ Illiterate \\
- $\quad$ Read and write \\
- Secondary \\
- University
\end{tabular} & $\begin{array}{l}4 \\
0 \\
1 \\
2\end{array}$ & $\begin{array}{l}4.0 \\
0.0 \\
1.0 \\
2.0\end{array}$ & $\begin{array}{c}42 \\
30 \\
19 \\
2\end{array}$ & $\begin{array}{c}42.0 \\
30.0 \\
19.0 \\
2.0\end{array}$ & 3.738 & 0.291 \\
\hline \begin{tabular}{|r|}
\multicolumn{2}{|l}{ Residence } \\
- Rural \\
- Urban
\end{tabular} & $\begin{array}{l}5 \\
2\end{array}$ & $\begin{array}{l}5.0 \\
2.0\end{array}$ & $\begin{array}{l}59 \\
34\end{array}$ & $\begin{array}{l}59.0 \\
34.0\end{array}$ & .180 & 0.671 \\
\hline Not significant $>0.05(\mathrm{NS})$ & *SigI & & $\overline{\text { S) }}$ & $* \mathbf{H}$ & nific & $\overline{\leq 0.001}$ \\
\hline
\end{tabular}


Table (4): Relation between Socio-demographic Characteristics of Patients with COPD and their Total Practice Scores: $(\mathrm{N}=100)$.

\begin{tabular}{|c|c|c|c|c|c|c|}
\hline Level of Practice & & & & $\begin{array}{l}\text { rectly } \\
86\end{array}$ & $\mathrm{X} 2$ & $\begin{array}{c}\mathbf{P} \\
\text { value }\end{array}$ \\
\hline $\begin{array}{l}\text { Sociodemographic } \\
\text { characteristics }\end{array}$ & No. & $\%$ & No. & $\%$ & & \\
\hline $\begin{array}{ll} & \text { Age in years: } \\
\text { 1) } 20- \\
\text { 2) } 40-60 \\
\end{array}$ & $\begin{array}{c}0 \\
14 \\
\end{array}$ & $\begin{array}{c}0.0 \\
14.0\end{array}$ & $\begin{array}{c}4 \\
82\end{array}$ & $\begin{array}{c}4.0 \\
82.0 \\
\end{array}$ & 0.678 & 0.410 \\
\hline $\begin{array}{l}\text { Gender: } \\
\text { 1) Male } \\
\text { 2) Female }\end{array}$ & $\begin{array}{c}12 \\
2\end{array}$ & $\begin{array}{c}12.0 \\
2.0\end{array}$ & $\begin{array}{c}80 \\
6\end{array}$ & $\begin{array}{c}80.0 \\
6.0\end{array}$ & 0.874 & 0.350 \\
\hline $\begin{array}{l}\text { Marital status: } \\
\text { 1) } \text { single } \\
\text { 2) married } \\
\text { 3) Divorced } \\
\text { 4) widow }\end{array}$ & $\begin{array}{l}0 \\
9 \\
1 \\
4\end{array}$ & $\begin{array}{l}0.0 \\
9.0 \\
1.0 \\
4.0\end{array}$ & $\begin{array}{c}4 \\
63 \\
9 \\
10\end{array}$ & $\begin{array}{c}4.0 \\
63.0 \\
9.0 \\
10.0\end{array}$ & 3.388 & 0.336 \\
\hline $\begin{array}{l}\text { Occupation } \\
\text { 1) Working } \\
\text { 2) Not working }\end{array}$ & $\begin{array}{c}11 \\
3\end{array}$ & $\begin{array}{c}11.0 \\
3.0\end{array}$ & $\begin{array}{l}43 \\
43\end{array}$ & $\begin{array}{l}43.0 \\
43.0\end{array}$ & 3.957 & $0.010 *$ \\
\hline \begin{aligned} \multicolumn{2}{l}{ Educational level } \\
1) Illiterate \\
2) Read and write \\
3) Secondary \\
4) University \end{aligned} & $\begin{array}{l}5 \\
4 \\
4 \\
1\end{array}$ & $\begin{array}{l}5.0 \\
4.0 \\
4.0 \\
1.0\end{array}$ & $\begin{array}{c}41 \\
26 \\
16 \\
3\end{array}$ & $\begin{array}{c}41.0 \\
26.0 \\
16.0 \\
3.0\end{array}$ & 1.385 & 0.709 \\
\hline \begin{aligned} \multicolumn{2}{l}{ Residence } \\
1) Rural \\
2) Urban \end{aligned} & $\begin{array}{l}8 \\
6\end{array}$ & $\begin{array}{l}8.0 \\
6.0\end{array}$ & $\begin{array}{l}56 \\
30\end{array}$ & $\begin{array}{l}56.0 \\
30.0\end{array}$ & 0.332 & 0.564 \\
\hline
\end{tabular}


Table (5): Relation between Socio-demographic Characteristics of Patients with COPD and their Total Self Efficacy Scores: $(\mathrm{N}=100)$.

\begin{tabular}{|c|c|c|c|c|c|c|}
\hline \multirow{2}{*}{$\begin{array}{l}\text { Total Self Efficacy } \\
\text { Sociodemographic } \\
\text { characteristics }\end{array}$} & \multicolumn{2}{|c|}{$\begin{array}{c}\text { High Self } \\
\text { Efficacy } \\
\text { No }=4\end{array}$} & \multicolumn{2}{|c|}{$\begin{array}{l}\text { Low Self } \\
\text { Efficacy } \\
\text { No= } 96\end{array}$} & \multirow[t]{2}{*}{$\mathbf{X} 2$} & \multirow[t]{2}{*}{$\begin{array}{c}\mathbf{P} \\
\text { value }\end{array}$} \\
\hline & No. & $\%$ & No. & $\%$ & & \\
\hline \multicolumn{7}{|l|}{ Age in years: } \\
\hline 1) $20-$ & 0 & 0.0 & 4 & 4.0 & 0.174 & 0.677 \\
\hline 2) $40-60$ & 4 & 4.0 & 92 & 92.0 & & \\
\hline \multicolumn{7}{|l|}{ Gender: } \\
\hline 1) Male & 4 & 4.0 & 88 & 88.0 & 0.362 & 0.547 \\
\hline 2) Female & 0 & 0.0 & 8 & 8.0 & & \\
\hline \multicolumn{7}{|l|}{ marital status: } \\
\hline 1) single & 0 & 0.0 & 4 & 4.0 & & \\
\hline 2) married & 3 & 3.0 & 69 & 69.0 & & \\
\hline 3) Divorced & 1 & 1.0 & 9 & 9.0 & 1.693 & 0.639 \\
\hline 4) widow & 0 & 0.0 & 14 & 14.0 & & \\
\hline \multicolumn{7}{|l|}{ Occupation } \\
\hline 1) Working & 4 & 4.0 & 50 & 50.0 & 3.549 & 0.060 \\
\hline 2) Not working & 0 & 0.0 & 46 & 46.0 & & \\
\hline \multicolumn{7}{|l|}{ Educational level } \\
\hline 1) Illiterate & 3 & 3.0 & 43 & 43.0 & & \\
\hline 2) Read and write & 0 & 0.0 & 30 & 30.0 & 7.439 & .059 \\
\hline 3) Secondary & 0 & 0.0 & 20 & 20.0 & & \\
\hline 4) University & 1 & 1.0 & 3 & 3.0 & & \\
\hline \multicolumn{7}{|l|}{ Residence } \\
\hline 1) Rural & 2 & 2.0 & 62 & 62.0 & 0.354 & 0.552 \\
\hline 2) Urban & 2 & 2.0 & 34 & 34.0 & & \\
\hline
\end{tabular}
(HS) 
Table (6): Relation between Patients' Knowledge, Practices, and Self Efficacy:

\begin{tabular}{|c|c|c|c|c|c|c|}
\hline & \multicolumn{4}{|c|}{ Level of Self Efficacy } & \multirow{3}{*}{$\mathbf{X}^{2}$} & \multirow{3}{*}{$P$ value } \\
\hline & \multicolumn{2}{|c|}{$\begin{array}{l}\text { High Self } \\
\text { Efficacy }\end{array}$} & \multicolumn{2}{|c|}{$\begin{array}{l}\text { Low Self } \\
\text { Efficacy }\end{array}$} & & \\
\hline & no. & $\%$ & no. & $\%$ & & \\
\hline $\begin{array}{l}\text { Total Knowledge } \\
\qquad \begin{array}{l}\text { Satisfactory }(\mathrm{no}=7) \\
>\begin{array}{l}\text { Un satisfactory } \\
(\text { no }=93)\end{array}\end{array}\end{array}$ & $\begin{array}{l}0 \\
4\end{array}$ & $\begin{array}{l}0.0 \\
4.0\end{array}$ & $\begin{array}{c}7 \\
89\end{array}$ & $\begin{array}{c}7.0 \\
89.0\end{array}$ & 0.314 & 0.575 \\
\hline $\begin{array}{l}\text { Total Practice } \\
\qquad \begin{aligned} & \text { Correctly done }(\mathrm{no}=14) \\
> & \begin{array}{l}\text { Incorrectly } \\
\text { done }(\mathrm{no}=86)\end{array}\end{aligned}\end{array}$ & $\begin{array}{l}1 \\
3\end{array}$ & $\begin{array}{l}1.0 \\
3.0\end{array}$ & $\begin{array}{l}13 \\
83\end{array}$ & $\begin{array}{l}13.0 \\
83.0\end{array}$ & 0.419 & 0.518 \\
\hline
\end{tabular}

(VS)

\section{Surrounding Home Pollutants}

vactories $\mathbf{n}$ homeanimals $\mathbf{n}$ rubbishburn airpollution

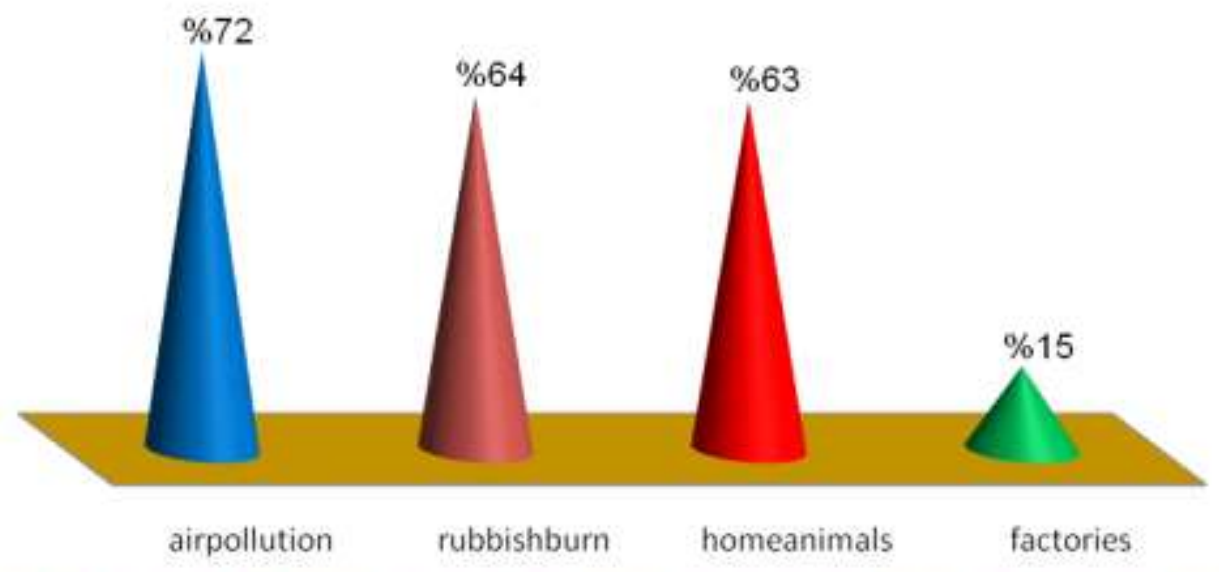

Figure (1): Surrounding's Home Pollutants of Patients with COPD 


\section{Body Mass Index}

i overweight

moderate obesity

in morbid obesity

-...-

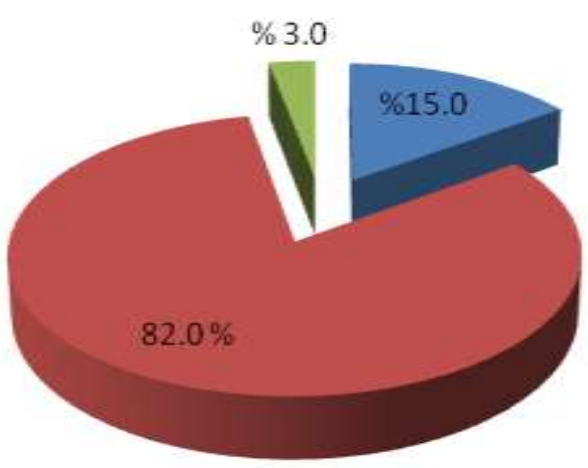

$(\mathrm{Mean} \pm \mathrm{SD}=\mathbf{3 3 . 4 9 5} \pm \mathbf{3 . 0 7})$

Figure (2): Body Mass Index of Patients with COPD.

\section{Total Knowledge}

nunsatisfactory atisfactory

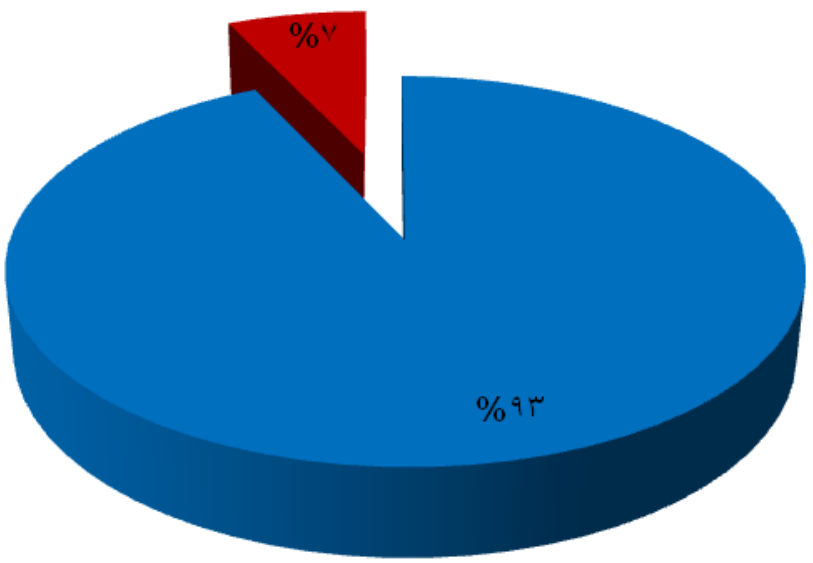


Figure (3)Total knowledge Scores of Patients with COPD.

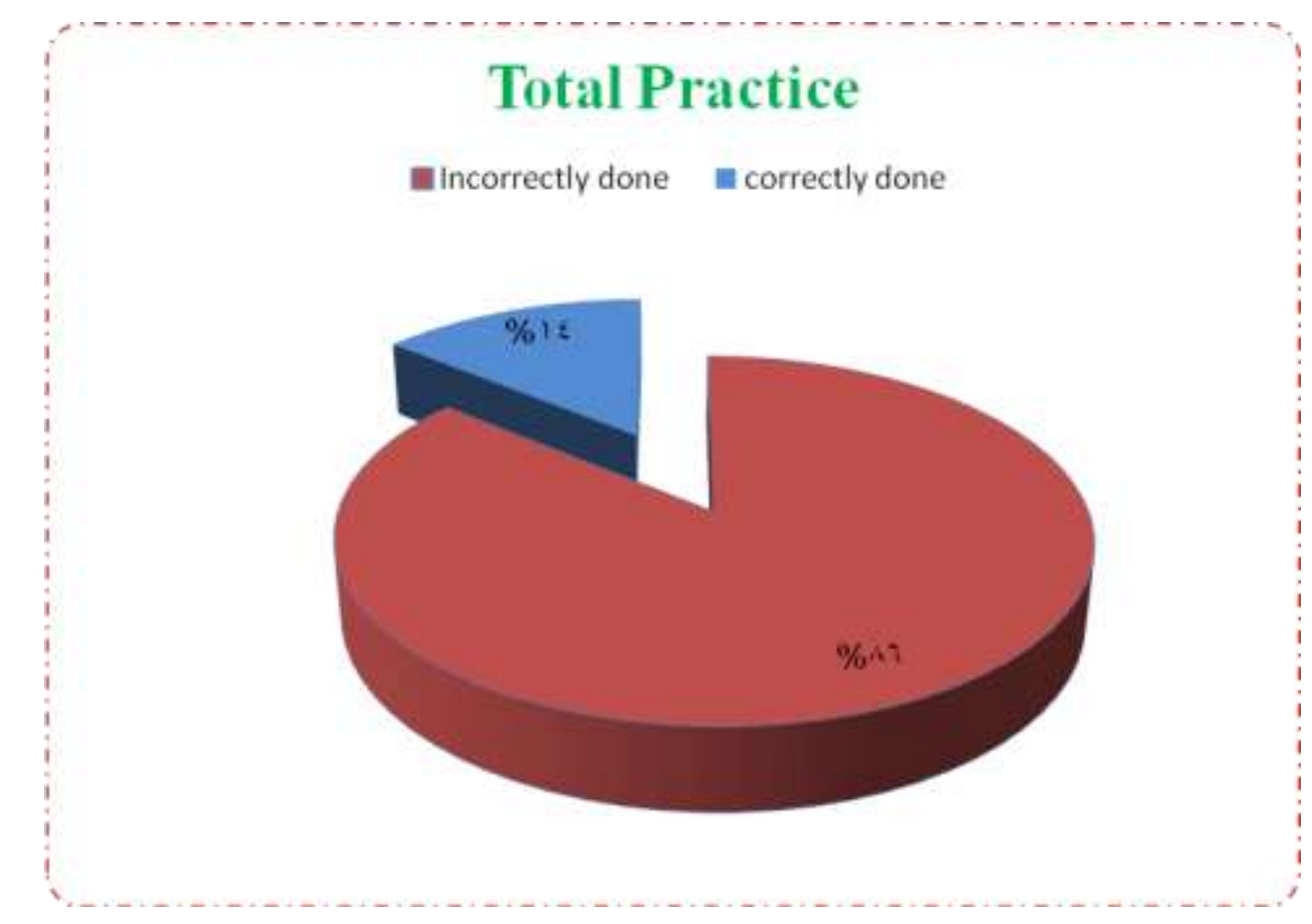

Figure (4): Total Practice Scores of the Patients with COPD.

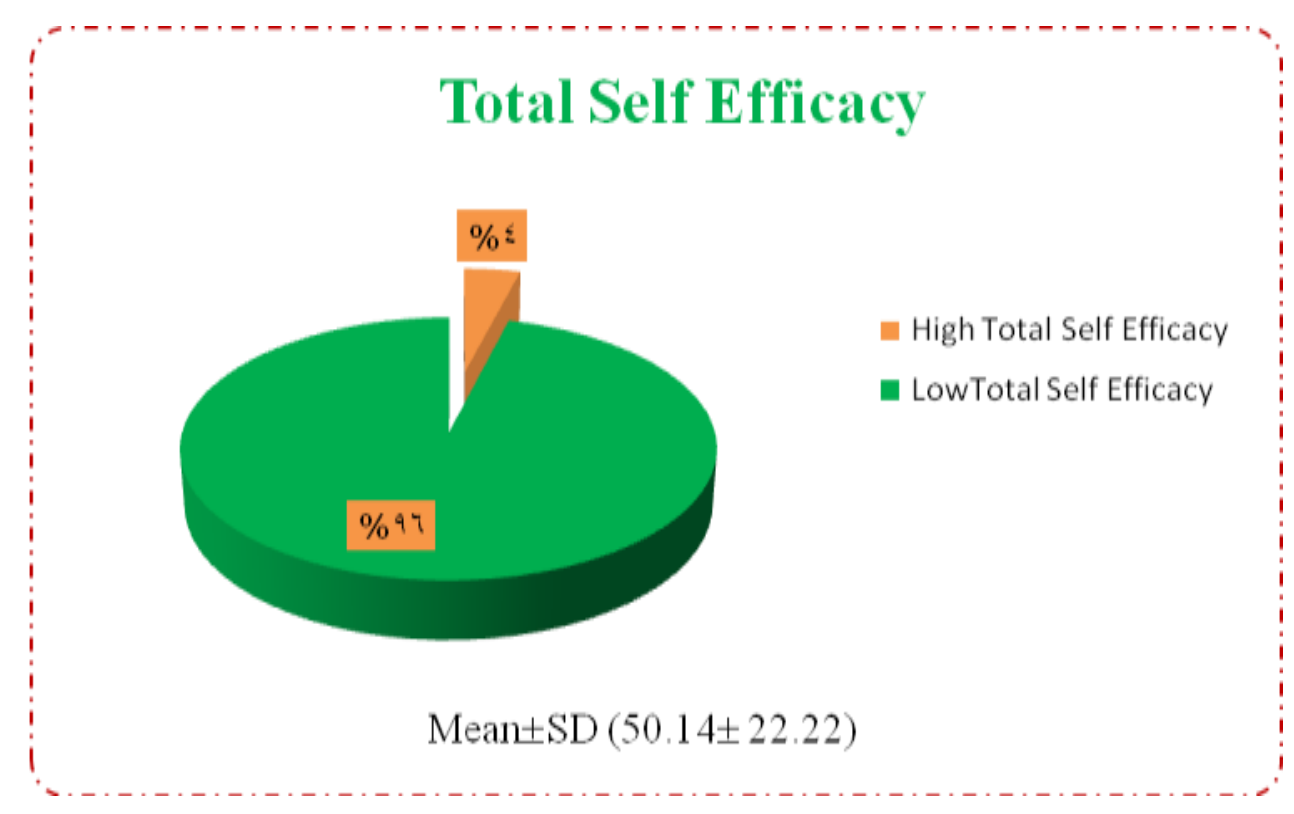

Figure (5): Total Self Efficacy Scores of Patients with COPD. 


\section{تقيم المعرفة والممارسات والكفاءة الذاتية لمرضي السدة الرئوية المزمنة}

أمورة عمر إبر اهيم الموافي، بهيه جلال عبد الرازق، ماجدة عبد العزيز محمد، أحمد السيد منصور

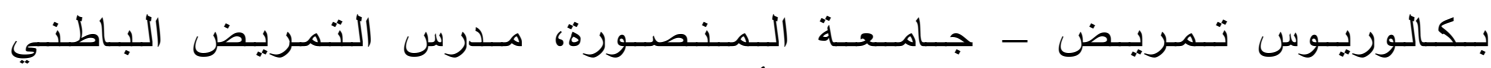

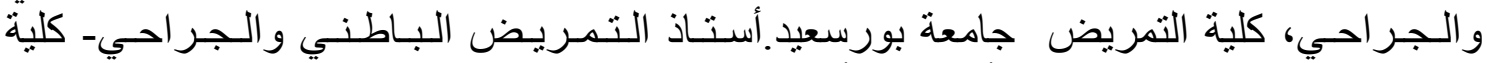

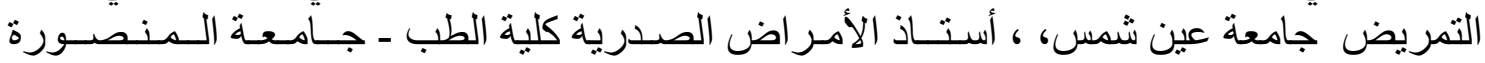

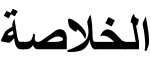

يمثل مرض السدة الرئوية المزمنة السبب الرابع الرئيسي للأمراض والوفيات في جميع أنحاء العالم، مما أدى إلى عبء اقتصادي واجتماعي كبير ومتز ايد. وكان الهدف من هذه الدراسة هو تقييم المعرفة و الممارسات و الكفاءة الذاتية لمرضى السدة الرئوية المزمنة. قد تم استخدام تصميم البحث الوصفي في هذه الدراسة. وتألفت العينة من مائة من المرضى الذين بعانون من مرض السدة الرئوية المزمنة في العيادة الخارجية لأمر اض الجهاز التففي بمستشفى جامعة المنصورة. استخدمت ثلاث أدوات لجمع البيانات و التى تتضمن استمارة استبيان مقابلة شخصية مكونة من الخصائص الاجتماعية و الديموغر افية للمريض وتاريخ المريض الطبي، و استمارة استبيان مقابلة شخصية لتقييم مستوى المعرفة والممارسات لمرضي السدة الرئوية المزمنة ، ومقياس الكفاءة الذاتية لمرضى السدة الرئوية المزمنة. وخلصت نتائج الدر اسة أن 96٪، 93\%، و 86.0٪ من المرضي لديهم مسنوي غير مرضي من المعلومات،كانت ممارساتهم غير مرضية وكان مستوي الكفاءة الذاتية لديهم قليل على التوالي. كان هنالك علاقة ذات دلالة إحصائية بين مستوى المعرفة لمرضي السدة الرئوية ووظيفتهم و علافة ذات دلالة إحصائية بين ممارسات المرضي ووظيفتهم. ومع ذلك لم يكن هناك علاقة ذات دلالة إحصائية بين مستوى المعرفة و الممارسات و الكفاءة الذاتية لديهم. وأوصت الدراسة بضرورة إجراء برنامج تعليمي لتحسين المعرفة و الممارسات و الكفاءة الذاتية لمرضى السدة الرئوية المزمنة . 